\title{
An introduction to the study on start-up success
}

\author{
Yehui Tong -Nanjing University of Finance and Economics, School of Accounting
}

Ramon Saladrigues Solé - University of Lleida

Abstract. Start-up success is an important topic of entrepreneurship research. This paper briefly introduces the main factors of success (survival, profitability and growth) and the related theories. In particular, the research on the resource-based view and industrial organization is highlighted. Financial capital and human capital are crucial start-up resources, and the related studies are considered under the resource-based view (including the previous studies about financing theory and financial constraints). Industrial organization is also a significant branch of research on a startup's post-entry performance, where particular attention is paid to the literature on innovation (together with some commonly used industry-specific factors in the previous research).

Keywords: start-up success, post-entry performance, resource-based view, and industrial organization.

JEL codes: M13, M00, L00.

\section{Introduction: start-up survival, profitability and growth}

Entrepreneurship is a hot research topic which has been studied by plenty of scholars, for it is seen as a powerful engine of economic development. For instance, the benefits of entrepreneurship on employment and GDP (gross domestic product) are documented in the studies by Doran et al. (2016) for Pan-European regions, and by Vázquez-Rozas et al. (2010) for Spanish and Portuguese regions. Furthermore, the contributions (through starting up businesses) by entrepreneurs to society are not limited just to job creation and adding economic value. The contributions also include product and process innovation, as well as detecting new markets (Bosma et al., 2002).

In fact, the history of the term "entrepreneurship" is over two hundred years, and the concept has various meanings: creation of wealth, creation of enterprise, creation of innovation, creation of change, creation of employment, creation of value, and creation of growth (Morris et al., 1994). From the perspective of business administration, entrepreneurship is related to the creation of new business organizations (Hoppe, 2016). Amason et al. (2006) further point out that the core of entrepreneurship is to explore and explain new venture success and failure; this is because failure incurs costs for the entrepreneur, creditors, other stakeholders and even for society (Eklund et al., 2018). 
Here the concept of newness or youngness should be discussed. Generally speaking, researchers are interested in the performance of start-ups in their first five years (more or less), and the reason behind this is that high hazard rates are exhibited during the first five years. For example, some researchers find nearly half of start-ups fail or are forced to stop operating during their first four or five years (Huyghebaert and Van de Gucht, 2004; Schrör, 2009; Mata and Portugal, 1994). In particular, the study by Konings et al. (1996) shows an increasing trend in the failure or exit rate in the first three years, and then a stable trend after that. Cefis and Marsili (2006) believe that firms that have been in existence for less than 5 years can be seen as young firms. From the perspectives of labor fluctuation and wage setting, Brixy et al. (2006) point out that the period for new firms to become incumbents is just a few years (three to five years).

\subsection{Factors of success}

Now that the concept of newness or youngness becomes clear, the features of new firms should be investigated in order to clarify the concept of success. Persson (2004) points out three features of new firms: low survival rates, survival rate increasing with the increase of firm age and size and growth decreasing with the increase of firm age and size. Based on previous research, Mcdougall et al. (1992) also state two important features of new businesses: a period of time before earning first profits and low survival rates. Furthermore, Suárez and Utterback (1995) state that survival is the basis for a firm's success in (for example) market share or profitability; Brüderl and Preisendörfer (1998) too point out that survival should be the minimum standard in measuring success.

Profit maximization (as the core objective of a firm's stockholders; Lieberman and Montgomery, 1988) should not be excluded from the success study. However, to some extent, the situation for new firms is different to that for the existing firms: it is difficult for new firms to earn profits. For example, as pointed out by Reynolds (2016), even after six years, only one third of new businesses can earn profits. A certain time period of surviving in order to earn profits causes many new firms to fail (Fritsch et al., 2006); while good profitability can promote survival, reduce the probability of default events and drive firm's growth in the long run (Bottazzi et al., 2010). In fact, if wealth maximization and survival could coexist, chasing optimality would be a firm's choice. However, if it is hard to harmonize wealth maximization and survival, firms tend to choose survival (Oprea, 2014). Furthermore, as stated by Audretsch (1995b), the expectation of future profits can help firms maintain a positive output, even if currently they are suffering losses.

\subsection{Growth}

Growth is frequently discussed in the literature of start-up performance, in addition to survival and profit. Although growth should be seen as the medium target for achieving survival and profits as the final goals, growth is usually studied as an independent and important element in firm performance. In particular, it is the characteristics of entrants that make growth important, i.e., smallness in size is an obvious feature of entrants (Mata, 1994). As pointed out by Santarelli and Vivarelli (2007), small entrants operate at a suboptimal size and they must grow in order to survive, so a higher growth rate is also a feature of small entrants (conditional on survival). 
Theoretically, the industrial organization theory shows that new firms often operate at a suboptimal level and suffer cost disadvantages, and growth is an important way to reduce this cost gap (Persson, 2004). In particular, when economies of scale exists, growth could reduce the average costs of small firms (Mata, 1994). Start-ups with a larger initial size do not need to grow much to reach the minimum efficiency scales, while start-ups with a smaller size need substantial growth (Audretsch, 1994). Notwithstanding, according to the research by Wagner (1994) on new and small single firms, about one third of the survivors show shrinking in size. Theoretically speaking, based on some previous studies, Rauch and Rijsdijk (2013) point out that growth can to some extent lead to failure, at least in the short term, because it reduces the owners' control and increases coordination requirements, resource deficits, and capacity shortages.

When researching on firm growth, one topic is ineluctable — Gibrat's law. Robert Gibrat (1931) found that a firm's growth is independent of its size. However, this law has been challenged by many researchers (like Gilbert, McDougall and Audretsch-2006), especially in the cases of new and small firms. For instance, Brusco, Giovannetti and Malagoli (1979) reveal that when it comes to surviving firms, the small ones show higher growth rates than the large ones; Evans (1987) discovered the existence of negative relationships between growth and size, as well as age, in most industries.

Based on previous literature, Mata and Portugal (2004) proposed several reasons to explain the phenomenon whereby surviving firms grow quickly during the post-entry period: according to the learning theory of Jovanovic (1982), firms can only know their true capabilities from observing their performance after operation, and so they tend to choose starting on a small scale and then growing, only if they perform well after operation. Start-up firms usually incur cash constraints which lead to a small-scale entry, and the firms showing good performance in their post-entry period earn internal funds as well as a good reputation with the banks (which provide conditions for growth); entering on a small scale and subsequently expanding can help firms avoid the aggression of incumbents and overcome entry barriers.

There are also some scholars studying the relationships of the three elements, for example, to identity the short- and long-term relationships between profitability, survival and growth. The study by Delmar, McKelvie, and Wennberg (2013) shows that good profitability undoubtedly would be beneficial to both survival and growth; growth can endanger survival but improve profitability; current growth can contribute to future growth, and the positive impacts of growth enhancing profitability can trigger further beneficial chain effects, thus benefiting firms in the long run.

\section{Theories about start-up performance}

Saridakis et al. (2008) point out that the factors affecting business failure can be summarized from three perspectives: industrial economics highlight profitability, growth, and entry and exit barriers; labor economics pay attention to business owners; and in the resource-based theory, managerial perspective focuses on the human capital, strategies, and constraints faced. In particular, they also point out that, according to the relative earnings model proposed by labor economists, in addition to the performance of the business, alternative sources of income may also drive business owners to 
quit business ownership (for example, when they believe that the utility of being employed by other firms or exiting from the labor force is better).

Organizational mortality is also an important topic of organizational ecology (Brüderl et al., 1992), which includes organizational strategies, organizational selection processes and environmental forces, and the "liability of newness" where young and new firms have a higher risk of failure than older ones (Stinchcombe 1965), and the "liability of smallness" where large new firms have better survival probability than new and small ones (Aldrich and Auster 1986). The organizational ecology approach highlights organizational characteristics and environmental conditions (exogeneous determinants) that suggest that a firm's size at birth could impact survival by reflecting its ability to attract financial resources (Persson, 2004).

\subsection{Resource-based View}

As pointed out by Aspelund et al. (2005), an organization's ability to survive is largely influenced by the characteristics of its resource bundle (for example, the resource's value, rarity, inimitability, and substitutability). The resource-based view highlights the effects of a firm's internal characteristics (as a source of competitive advantage) and a firm's ability to develop different resources and capabilities (as a result of strategic choices) based on various outcomes, according to the belief that firms are heterogeneous with different tangible and intangible resources and capabilities (Esteve-Pérez and Mańez-Castillejo, 2008). Here, two important resources regarding entrepreneurial performance are discussed: financial capital and human capital (Gilbert et al., 2006; Parker and Van Praag, 2006).

\section{a. Financial capital and financing constraints}

Financial capital plays an important role in new firm performance, because whether or not a new firm can obtain suitable financing resources often determines its success or failure (Berger and Udell, 2002; Chandler and Hanks, 1998). As pointed out by Fraser et al. (2015), different types of firms have different preferences on sources of financing: growth orientated firms are interested in external finance, whereas less dynamic firms prefer internal finance. However, compared to large and mature firms, young and small firms find them difficult to access external funds (Musso and Schiavo, 2008). Start-ups usually are faced with the risk of failure and financial constraints (Huyghebaert, 2006). Financial constraints can have a negative and long-term impact on a start-up's performance (Tobias, 2013), since (for instance) holding sufficient funds is the foundation for building high quality human capital, introducing high-level production technology and consequently achieving high productivity (Greene, 1997).

The significant influence of financial constraints notwithstanding, the measurement of financial constraints depends on researchers. Fraser et al. (2015) believe that financial constraints are shown in the relationship between the availability of internal finance and investment (growth) or, more directly, the relationship between funding gaps and business outcomes. On the other hand, other researchers have their own measuring methods: severity scoring on a four point scale (Saridakis et al., 2007), dividend payout ratios (Fazzari, 1988), credit rating index (Bottazzi et al., 2014), and a synthetic index based on several financial variables (Musso and Schiavo, 2008). 
Although it is still arguable whether financial constraints can in effect discourage potential entrepreneurs to pursue their entrepreneurship dream (Fjærli, and Iancu, 2012), a particular aspect related to financial constraints is founders' wealth. In fact, some scholars find that a start-up's size is positively related to the founders' wealth (Cabral and Mata, 2003; Hvide and Møen, 2010). Additionally, the study by Evans and Jovanovic (1989) deserves to be mentioned here. Their mode firstly identifies entrepreneur's capacity and initial wealth separately, and then they find that the disparity between the two elements would impede entrepreneurship (especially in the case of capable entrepreneurs with less wealth —i.e. suffering financial constraints).

\section{Financial characteristics of start-ups}

Huyghebaert and Van de Gucht (2007) point out some characteristics of start-ups which could influence the financing decisions: information asymmetry is an obvious problem of start-ups for outside financiers (which is caused by no historical data); highly concentrated ownership in startups causes less agency costs; private benefits of control (for example, prestige and the power to decide on business strategy) are important for the owners of start-ups.

Small and micro firms comprise the main body of start-ups, and the shortage of equity capital is an important problem hindering start-up founders to obtain loans from banks due to a lack of collateral (Egeln et al., 1997). In addition, there is the problem of asymmetric information between the owners and managers of a firm and between owners and outside investors, although this problem could be alleviated as time goes by (Brito and Mello, 1995). Information asymmetries could increase the costs when new firms introduce external finance, because lenders tend to charge higher interest rate to compensate for the additional risk (Atherton, 2012). With imperfect information, internally retained funds are cheaper than external capital, as investors find it difficult to precisely evaluate a firm's future prospects and the quality of the management team (Brito and Mello, 1995).

In particular, asymmetric information can lead to the problems of adverse selection and moral hazard in external finance, especially for small firms (Carpenter and Petersen, 2002). Paul et al. (2007) give some detailed explanations about adverse selection and moral hazard; i.e. adverse selection occurs because, when introducing financing, entrepreneurs tend to emphasize the strengths and hide the weakness of their business, and the moral hazard arises when entrepreneurs may take advantage of asymmetric information for their own benefits at the cost of investors (for example, investing in a project with higher risk). As a result, information asymmetry would mean more expensive external financing and make other sources outstanding. In fact, when being faced with asymmetric information problems, internal resources are used as a substitute to external finance (La Rocca et al., 2011). However, because new businesses require a period of time to earn the first profits and to be competitive with incumbents (Mcdougall et al., 1992; Cincera and Galgau, 2005), it would not be easy to use retained profits as internal financing. Therefore, access to external finance still plays an important role (La Rocca et al., 2011). 


\section{Capital structure theories}

Modigliani and Miller (1958) open the door for researching the impacts of capital structure on firm value and performance, although its condition in a perfectly efficient market is virtually nonexistent. Further, in 1963, they identified the tax shield effects, indicating that firms can benefit from leverage by deducting tax on interest payments. Another influential theory coming after Modigliani and Miller is the agency theory, proposed by Jensen and Meckling (1976). They verify the existence of agency costs between owners, creditors and customers, and further deem that the most effective capital structure should balance the trade-off between the benefits and costs of increasing debt; for example, balancing tax benefits and financial distress costs (Cassar and Holmes, 2003).

On the other hand, the pecking order theory, proposed by Myers (1984) and Myers and Majluf (1984), says that firms prefer internal to external finance, and (when introducing external funds) debt ranks before equity (Paul et al., 2007). There are two possible reasons proving the suitability of the pecking order theory for new firms: first, information asymmetry (especially less historical data in start-ups) hinders decision-making on investments; second, entrepreneurs would lose less control of their business by introducing bank loans, as opposed to issuing new equity (Paul et al., 2007).

\section{Bootstrapping}

In the early business stage, entrepreneurs usually rely more on personal or internally generated funds, and try to control costs and manage capital expenditures (Brush, 2008). This introduces a non-traditional concept for financially constrained new and small firms, namely bootstrapping. Bootstrap financings are the financing methods that are usually different to the traditional financing from financial institutions and personal equity, so they can be seen as alternatives for the firms lacking access to traditional sources (Carter and Van Auken, 2005). As stated by Lahm and Little (2005), in fact bootstrapping (as the purest form of entrepreneurship) converts human capital into financial capital.

Bootstrapping means conserving financial resources and managing cash in a resourceful manner (particularly also minimizing the need for financing and acquiring resources creatively), as a way of overcoming the difficulties that small and new firms face when obtaining capital (Brush, 2008). As summarized by Van Auken (2005), the advantages of bootstrap financing include that it is easy to obtain, it is convenient, it minimizes requirements, and it makes a business plan or collateral unnecessary. In fact, recent papers find that both the firms with financial constraints and the firms with relatively sufficient funds tend to use financial bootstrapping due to its positive economic influence (Winborg, 2009).

With respect to financial bootstrapping, different scholars may have different forms of classification. For example, Freer et al. (1995) divide financial bootstrapping techniques into four groups according to the purpose; including for product development, for business development, to minimize the need for outside capital and to minimize the need for internal capital. Furthermore, Harrison et al. (2004) find that, compared with product development bootstrapping techniques, business development bootstrapping techniques are used more often by small firms. However, the widely cited classification is proposed by Winborg and Landström (2001), where there are six groups of financial bootstrapping methods: owner-financing (resources from the owner, manager, and relatives); minimization of accounts receivable; joint utilization (sharing and borrowing 
resources from other businesses); delaying payments; minimization of capital invested in stock; subsidy finance (obtaining subsidies from public organizations).

Here, two types of financial bootstrapping techniques need to be highlighted particularly, namely the entrepreneur's personal savings and loans from friends and relatives as well as subsidies. Bosma et al. (2002) stress the significant role of the entrepreneur's personal savings and loans from friends and relatives to start-ups. In terms of subsidy, Arshakuni, and Kamionka (2007) find that subsidies not only have an impact on financing per se, but also influence accessing bank loans. Besides, Crepon and Duguet (2003) argue that subsidies are more powerful than bank loans in supporting start-ups, particularly in terms of the survival of start-ups created by needy entrepreneurs (who were unemployed before becoming entrepreneurs). Nevertheless, Lahm and Little (2005) believe that the effect of bootstrapping on an organization's success has not been fully recognized.

\section{b. Human capital}

The human capital theory is useful for explaining the growth and failure of business ventures, and it is earned from the financial returns on employees so as to maximize the economic benefits and therefore compensate investments in human capital (Rauch and Rijsdijk, 2013). The firms with more or higher quality human capital should have advantages in perceiving profitable opportunities for new economic activity and in successfully exploiting these opportunities (Davidsson and Honig, 2003). A firm can gain human capital by evaluating new ventures and learning about business and the environment (Cassar, 2014).

As pointed out by Brüderl et al. (1992), entrepreneurial human capital can be further classified into general human capital (such as, education and work experience) and specific human capital (for instance, industry-specific experience). Rauch and Rijsdijk (2013) further state that general human capital increases opportunity costs and can be applied in different contexts. It serves as a source of knowledge, skills and problem-solving abilities, and motivates people to acquire new knowledge. Specific human capital is helpful when operating a business (for example, industryspecific experience includes ways to find profitable niches and increase productivity). From the perspective of empirical study, it has been found that both general and specific human capital have positive impacts on the survival of new firms; and, the accumulative effects of human capital, which means the number of founding entrepreneurs, is positively related to new firm survival (Arribas and Vila, 2007).

\section{Education}

Making entrepreneurial decisions needs to use both tacit (i.e. know-how) and explicit (i.e. knowwhat) knowledge, which can be obtained from formal education (university education), informal education (work experience), and non-formal education (adult education). In particular, formal education can help to accumulate explicit knowledge, providing entrepreneurs with useful skills, while entrepreneurs gain important tacit knowledge from previous work and start-up experiences (Davidsson and Honig, 2003). As an empirical study, Parker and Van Praag (2006) focus on education when researching the impact of human capital, and it is measured as the number of years of schooling; in particular, they find that more years of education can lead directly to better entrepreneurial performance and it can also help to alleviate capital constraints. 


\section{Prior start-up experience and industry experience}

The founding team's previous start-up and industry experience is studied in depth by Delmar and Shane (2006). This is because they believe that prior start-up experience (the previous experience of creating new organizations) can help to identify and evaluate opportunities, acquire resources and organize the firm, while industry experience (previous work in the new firm's industrial field) is helpful when it comes to industry rules and norms, customer and supplier networks, and employment practices.

Muñoz-Bullon et al. (2015) point out that the team's previous experience in start-ups and industry has a moderating effect on the relationship between the resources brought from the team and creating a profitable business. In particular, they believe that experience can increase the ability of nascent entrepreneurs to manage team resources more effectively, and this can further influence the nascent entrepreneur's expectations to overcome the liability of being a new firm, and therefore create a profitable business. In spite of this, different opinions still exist: for example, the study by Cassar (2014) shows that industry experience (rather than start-up experience) is useful in predicting new business performance.

\subsection{Industrial organization}

The traditional industrial organization theory (which assumes the homogeneity of production technologies and products) believes that new entrants can work as an equilibrating force to push profitability and price to their long-run competitive levels (Tveterås and Eide, 2000). In particular, Audretsch and Mata (1995) state that the traditional view in industrial organization attributes firm entry to profits in excess of equilibrium in an industry. Furthermore, they also point out the importance of studying the post-entry performance of firms, i.e., to understand the selection process of markets (why some survive and others fail).

Audretsch et al. (1999) summarized the theoretical model of noisy selection by Jovanovic (1982) as follows: randomness exists in a firm's survival; the costs of new entrants are not only random but also different between firms; a new firm can only learn its cost function (relative efficiency) in its post-entry performance; the firms that are found to be efficient will survive and grow, whereas the inefficient ones will fail; being independent of both firm and industry specific characteristics, the post-entry growth rates of new firms should also be stochastically distributed.

Usually, the founding conditions can have a long-term impact on new firms (Eisenhardt and Schoonhoven, 1990). In particular, Sharma and Kesner (1996) point out that the importance of industry conditions for new entrants, at the time of entry, could be explained in two facets: the first is sunk costs (the irrecoverable investments by entrants to build their capacity in order to compete with incumbents, and being lost permanently) that affect industry dynamics and firm profitability profoundly; the second is that industry conditions include behavioral entry barriers, especially the retaliation from incumbents (because new entrants may threaten the market position and profitability of existing firms). 


\section{Some industry-specific factors}

Bellone et al. (2008) identify industry characteristics as industry dynamic features (turbulence) and industry static features (market structure). To be precise, industry sales growth and industry entry represent industry turbulence, while the size of the market and the industry concentration represent market structure and then industry maturity. Furthermore, they find that the impacts of industry dynamic features (turbulence) are more important than those caused by the static features (market structure).

As pointed out by some scholars, there is a positive relationship between entry rate and exit rate (Dunne et al., 1988; Bartelsman, 2005), due to high competition caused by high industry entry (Fritsch et al., 2006). However, in the industries with a high growth of sale, the situation may be different: the incumbents would face much less pressure from the entrants, and suffer less market share losses, thus causing less retaliation (Mata and Portugal, 1994). In addition, an increase in price-cost-margins driven by an increase in demand can benefit firms in the fast-growing industries (Strotmann, 2007).

Regarding the question of who exits (new entrants or incumbents), Audretsch (1995b, p592) uses two metaphors to answer this. "The evidence suggests that the process of firm selection may be better characterized by the revolving door metaphor in markets where scale economies play an important role and where innovative activity is dominated by large enterprises. By contrast, the forest metaphor with the new saplings overtaking the old large trees may be more applicable in industries where the underlying technological conditions closely conform to the entrepreneurial regime."

With regard to industry concentration, traditional view believes that in high concentration industry (which signifies market imperfection), the firms with low market power (like young firms) are more likely to exit (Bellone et al., 2008). This is because, in high concentration industry, existing firms may collude together to control the market and resist entrants (Bunch and Smiley, 1992). Notwithstanding, suboptimal scale new firms may still have survival space in highly concentrated industries (López-García and Puente, 2006). As pointed out by Geroski et al. (2009), although new entrants may be highly resisted at first and thus have a high probability of failure, if the entrants can remain standing for more than one year, they would be accepted as a club member by the incumbents and then would achieve high profitability levels and manifest a high survival rate thereafter.

\section{Innovation studies at industrial level}

In reality, highly innovative industries are attractive to the new firms hoping to innovate, but they reveal a higher failure rate (Audretsch, 1995a). To explain this, Audretsch (1995b) points out that technological and demand characteristics of the industry have a large impact on whether an establishment stays or fails. In fact, technological activity (or technological environment) is an important factor affecting firm's entry, exit, survival, and growth (Agarwal, 1998). As stated by Marsili (2002), innovative activities in research and development $(\mathrm{R} \& \mathrm{D})$ are treated as one kind of entry barrier (a technological entry barrier relating to the influence of technology on new innovation opportunities for new firms as opposed to incumbents); and, in particular, the characteristics of innovation processes in different industrial sectors and different technological 
environments (favoring an "entrepreneurial" pattern or "routinised" pattern) lead to the factor creating different impacts on innovative entrepreneurship.

Audretsch (1995a) finds that a highly innovative environment has an ambiguous influence on post-entry performance. On the one hand, using innovative activity to differentiate products is a crucial strategy used by entrants to offset size disadvantages and gain a small market share. On the other hand, a highly innovative environment is disadvantageous to post-entry survival during the first few years, and Audretsch (1995a) attributes this phenomenon to the different ways that innovative activity is generated between industries; i.e., new economic knowledge innovations are easily processed by incumbents in relatively routine industries (stressing the importance of information based on non-transferable experience in the market when generating innovative activity), while new firms tend to have an advantage over incumbents in the industries where innovations evolve out of a natural routine (information outside routine is an important input when generating innovative activity).

The study by Jensen et al. (2008) shows that, compared to their established counterparts, new firms show advantages in innovative industries. For example, they state that the agility of new firms is important in innovative industries, while in less innovative industries the importance of conventional factors (like size and financial assets) overrides the significance of change and newness. On the other hand, Cefis and Marsili (2006) did research on the influence of innovation as a strategy on survival (the survival of innovators and non-innovators) for entrepreneurial firms and established firms in different technological environments (high-tech and low-tech manufacturing sectors). Particularly, as for entrepreneurial firms, their findings stress the crucial role of innovative activity in both high-tech and low-tech sectors.

\section{Conclusions}

This paper provides a brief introduction to the study on start-up success with a review of related theoretical studies. The first question that needs to be addressed is "what is success?". The answers here are survival, profitability and growth. Although there are also other success factors, the importance of survival, profitability and growth to start-ups is undeniable (and can be verified by plenty of research literature focusing on these three factors). In particular, survival is the basic standard of success, and earning profits is the final target, while growth is an important method for achieving the previous two targets.

The second part of this paper reviews the theories on start-ups, especially the resource-based view and industrial organization. Review of the resource-based theory focuses on financial capital and human capital. In particular, financial constraints (as an important problem faced by start-ups) are studied in depth, together with related financing theories. As for the industrial organization theory, there are a number of studies focusing on a start-up's post-entry performance. Here, apart from some commonly studied industry-specific factors (industry concentration, industry growth and industry entry), we find a particular review of the research on innovation (from the perspective of industrial organization) so as to clarify the differences between the contributions made by entrants and incumbents to innovative activities. All in all, this paper provides a general overview which can help people gain insight into the research on start-up success. 


\section{Reference}

Agarwal, R., (1998). "Small firm survival and technological activity". Small Business Economics, 11 (3), pp. 215-224.

Aldrich, H.E., and Auster, E., (1986). "Even dwarfs started small: Liabilities of age and size and their strategic implications". Research in Organizational Behavior, 8, pp. 165-198.

Amason, A.C., Shrader, R.C. and Tompson, G.H., (2006). "Newness and novelty: Relating top management team composition to new venture performance”. Journal of Business Venturing, 21 (1), pp. 125-148.

Arribas, I., and Vila, J.E., (2007). "Human capital determinants of the survival of entrepreneurial service firms in Spain”. International Entrepreneurship and Management Journal, 3 (3), pp. 309-322.

Arrighetti, A. and Vivarelli, M., (1999). "The role of innovation in the postentry performance of new small firms: Evidence from Italy”. Southern Economic Journal, 65 (4), pp. 927-939.

Arshakuni, K., and Kamionka, T., (2007). New small start-ups dynamics with endogenous initial capital, bank loan and public aids. University Paris 1 Pantheon-Sorbonne (TEAM). http://www. wise.xmu.edu.cn/panel2007/paper/KAMIONKA(Thierry).pdf.

Aspelund, A., Berg-Utby, T., and Skjevdal, R., (2005). "Initial resources' influence on new venture survival: a longitudinal study of new technology-based firms”. Technovation, 25 (11), pp. 1337 1347.

Atherton, A., (2012). "Cases of start-up financing: An analysis of new venture capitalisation structures and patterns”. International Journal of Entrepreneurial Behavior \& Research, 18 (1), pp. 28-47,

Audretsch, D.B. and Mata, J., (1995). "The post-entry performance of firms: Introduction". International Journal of Industrial Organization, 13 (4), pp. 413-419.

Audretsch, D.B., (1995a). "Innovation, growth and survival". International Journal of Industrial Organization, 13(4), pp. 441-457.

Audretsch, D.B., (1995b). "The propensity to exit and innovation". Review of Industrial Organization, 10(5), pp. 589-605.

Audretsch, D.B., Santarelli, E., and Vivarelli, M., (1999). "Start-up size and industrial dynamics: Some evidence from Italian manufacturing". International Journal of Industrial Organization, 17 (7), pp. 965-983.

Audretsch, D.B., (1994). "Business survival and the decision to exit". International Journal of the Economics of Business, 1 (1), pp. 125-137.

Barron, D.N., West, E., and Hannan, M.T., (1994). "A time to grow and a time to die: Growth and mortality of credit unions in New York City", 1914-1990. American Journal of Sociology, 100(2), pp. 381-421.

Bartelsman, E., Scarpetta, S., and Schivardi, F., (2005). "Comparative analysis of firm demographics and survival: evidence from micro-level sources in OECD countries”. Industrial and Corporate Change, 14(3), pp. 365-391.

Bellone, F., Musso, P., Nesta, L., and Quéré, M., (2008). "Market selection along the firm life cycle". Industrial and Corporate Change, 17(4), pp. 753-777. 
Berger, A.N., and Udell, G.F., (2002). "Small business credit availability and relationship lending: The importance of bank organizational structure". The Economic Journal, 112 (477), pp. F32-F53.

Bottazzi, G., Secchi, A., and Tamagni, F., (2014). "Financial constraints and firm dynamics". Small Business Economics, 42(1), pp. 99-116.

De Wit, G., Bosma, N., and van Praag, M., (2002). "Entrepreneurial venture performance and initial capital constraints". No H200205, Scales Research Reports from EIM Business and Policy Research http://www.entrepreneurship-sme.eu/pdf-ez/H200205.pdf.

Bottazzi, G., Grazzi, M., Secchi, A., and Tamagni, F., (2011). "Financial and economic determinants of firm default". Journal of Evolutionary Economics, 21 (3), pp. 373-406.

Brixy, U., Kohaut, S., and Schnabel, C., (2006). "How fast do newly founded firms mature? Empirical analyses on job quality in start-ups”. In: Fritsch M., Schmude J. (eds) Entrepreneurship in the Region. International Studies in Entrepreneurship, 14, pp. 95-112, Springer, Boston, MA.

Brito, P., and Mello, A.S., (1995). "Financial constraints and firm post-entry performance". International Journal of Industrial Organization, 13 (4), pp. 543-565.

Brüderl, J., and Preisendörfer, P., (1998). "Network support and the success of newly founded business”. Small Business Economics, 10 (3), pp. 213-225.

Brüderl, J., Preisendörfer, P., and Ziegler, R., (1992). "Survival chances of newly founded business organizations”. American Sociological Review, 57 (2), pp. 227-242.

Brüderl, J., and Schüssler, R., (1990). "Organizational mortality: The liabilities of newness and adolescence”. Administrative Science Quarterly, 35(3), pp. 530-547.

Brush, C.G., (2008). "Pioneering strategies for entrepreneurial success". Business Horizons, 51 (1), pp. 21-27.

Buddelmeyer, H., Jensen, P.H., and Webster, E., (2010). "Innovation and the determinants of company survival”. Oxford Economic Papers, 62(2), pp. 261-285.

Bunch, D.S., and Smiley, R., (1992). "Who deters entry? Evidence on the use of strategic entry deterrents". The Review of Economics and Statistics, 74(3), pp. 509-521.

Cabral, L.M.B., and Mata, J., (2003). "On the evolution of firm size distribution: Facts and theory". The American economic review, 93 (4), pp. 1075-1090.

Carpenter, R.E., and Petersen, B.C., (2002). "Is the growth of small firms constrained by internal finance?" The Review of Economics and Statistics, 84(2), pp. 298-309.

Carter, R.B. and Van Auken, H., (2005). "Bootstrap financing and owners' perceptions of their business constraints and opportunities”. Entrepreneurship \& Regional Development, 17 (2), pp. 129-144.

Cassar, G., (2014). "Industry and startup experience on entrepreneur forecast performance in new firms". Journal of Business Venturing, 29 (1), pp. 137-151.

Cassar, G., and Holmes, S., (2003). "Capital structure and financing of SMEs: Australian evidence”. Accounting and finance, 43(2), pp. 123-147.

Cefis, E., and Marsili, O., (2006). "Survivor: The role of innovation in firms' survival". Research Policy, 35(5), pp. 626-641. 
Chandler, G.N., and Hanks, S.H., (1998). "An examination of the substitutability of founders human and financial capital in emerging business ventures". Journal of Business Venturing, 13 (5), pp. 353-369.

Cincera, M., and Galgau, O., (2005). Impact of market entry and exit on EU productivity and growth performance. No. 222, European Economy - Economic Papers 2008 - 2015 from Directorate General Economic and Financial Affairs (DG ECFIN), European Commission. http://ec.europa.eu/economy_finance/publications/pages/publication712_en.pdf.

Crépon B., and Duguet, E., (2003). Bank loans, start-up subsidies and the survival of the new firms: an econometric analysis at the entrepreneur level. University of Paris I, Working Paper, No. 2003.77. https://ssrn.com/abstract=421921.

Davidsson, P. and Honig, B., (2003). "The role of social and human capital among nascent entrepreneurs". Journal of Business Venturing, 18(3), pp. 301-331.

Delmar, F., and Shane, S., (2006). "Does experience matter? The effect of founding team experience on the survival and sales of newly founded ventures". Strategic Organization, 4(3), pp. 215-247.

Delmar, F., McKelvie, A., and Wennberg, K., (2013). "Untangling the relationships among growth, profitability and survival in new firms". Technovation, 33 (8-9), pp. 276-291.

Doran, J., McCarthy, N., and O'Connor, M., (2016). "Entrepreneurship and employment growth across European regions”. Regional Studies, Regional Science, 3(1), pp. 121-128.

Dunne, T., Roberts, M.J., and Samuelson, L., (1988). "Patterns of firm entry and exit in U.S. manufacturing industries". The RAND Journal of Economics, 19(4), pp. 495-515.

Egeln, J., Licht, G., and Steil, F. (1997). "Firm foundations and the role of financial constraints". Small Business Economics, 9(2), pp. 137-150.

Eisenhardt, K.M., and Schoonhoven, C.B., (1990). "Organizational growth: Linking founding team, strategy, environment, and growth among U.S. semiconductor ventures", 1978-1988. Administrative Science Quarterly, 35(3), pp. 504-529.

Eklund, J., Levratto, N., and Ramello, G.B., (2018). "Entrepreneurship and failure: two sides of the same coin?”. Small Business Economics, pp. 1-10.

Esteve-Pérez, S., and Mañez-Castillejo, J.A., (2008). "The resource-based theory of the firm and firm survival”. Small Business Economics, 30 (3), pp. 231-249.

Evans, D., (1987). "The relationship between firm growth, size, and age: Estimates for 100 manufacturing industries". The Journal of Industrial Economics, 35(4), The Empirical Renaissance in Industrial Economics, pp. 567-581.

Evans, D.S., and Jovanovic, B., (1989). "An estimated model of entrepreneurial choice under liquidity constraints". Journal of Political Economy, 97(4), pp. 808-827.

Fazzari, S.M., Hubbard, R.G. and Petersen, B.C., (1988). "Financing constraints and corporate investment”. Brookings Papers on Economic Activity, 1988 (1), pp. 141-206.

Fjærli, E., and Iancu, D., (2012). The financing of young firms. How persistent are borrowing constraints?. Discussion Papers, No. 707, October 2012, Statistics Norway, Research Department https://www.ssb.no/a/publikasjoner/pdf/DP/dp707.pdf.

Fraser, S., Bhaumik, S.K., and Wright, M., (2015). "What do we know about entrepreneurial finance and its relationship with growth?”. International Small Business Journal: Researching Entrepreneurship, 33(1), pp. 70-88. 
Fritsch, M., Brixy, U., and Falck, O., (2006). "The effect of industry, region, and time on new business survival - A multi-dimensional analysis”. Review of Industrial Organization, 28 (3), pp. 285-306.

Geroski, P. A., Mata, J., and Portugal, P., (2010). "Founding conditions and the survival of new firms”. Strategic Management Journal, 31(5), pp. 510-529.

Gibrat, R., (1931). Les inégalités économiques. Paris, Librairie du Recueil Sirey.

Gilbert, B.A., McDougall, P.P., and Audretsch, D.B., (2006). "New venture growth: A review and extension”. Journal of Management, 32 (6), pp. 926-950.

Hansen, J.A., (1992). "Innovation, firm size, and firm age”. Small Business Economics, 4 (1), pp. $37-44$.

Hoppe, M., (2016). “The entrepreneurship concept: A short introduction”. Högre utbildning, 6(2), pp. 95-108.

Huyghebaert, N., and Van de Gucht, L. M., (2007). "The determinants of financial structure: New insights from business start-ups". European Financial Management, 13 (1), pp. 101-133.

Huyghebaert, N., (2006). "On the determinants and dynamics of trade credit use: Empirical evidence from business start-ups". Journal of Business Finance \& Accounting, 33(1) \& (2), pp. 305-328.

Huyghebaert, N., and Van de Gucht, L. M., (2004). "Incumbent strategic behavior in financial markets and the exit of entrepreneurial start-ups”. Strategic Management Journal, 25 (7), pp. 669-688.

Hvide, H.K., and Møen, J., (2010). "Lean and hungry or fat and content? Entrepreneurs' wealth and start-up performance”. Management Science, 56(8), pp. 1242-1258.

Jensen, M.C., and Meckling, W.H., (1976). "Theory of the firm: Managerial behaviour, agency costs and ownership structure". Journal of Financial Economics, 3(4), pp. 305-360.

Jovanovic, B., (1982). "Selection and the evolution of industry". Econometrica, 50(3), pp. 649670.

Konings, J., Roodhooft, F., and Van de Gucht, L., (1996). The life cycle of new firms and its impact on job creation and job destruction. K.U. Leuven - Departement toegepaste economische wetenschappen, DTEW Research Report 09669, pp. 1-34. https://lirias.kuleuven.be/ bitstream/123456789/220528/1/OR_9669.pdf.

Lahm, R.J., Jr., and Little, H.T., Jr., (2005). "Bootstrapping business start-ups: entrepreneurship literature, textbooks, and teaching practices versus current business practices?” Journal of Entrepreneurship Education, 8, pp. 61-73.

La Rocca, M., La Rocca, T., and Cariola, A., (2011). "Capital structure decisions during a firm's life cycle”. Small Bussiness Economics, 37(1), pp. 107-130.

Lieberman, M.B., and Montgomery, D.B., (1988). "First-mover advantages". Strategic Management Journal, 9(S1), Special Issue: Strategy Content Research, pp. 41-58.

López-García, P., and Puente, S., (2006). Business demography in Spain: Determinants of firm survival. Banco de España Research Paper No. WP-0608. http:/www.bde.es/f/webbde/SES/ Secciones/Publicaciones/PublicacionesSeriadas/DocumentosTrabajo/06/Fic/dt0608e.pdf. 
Mcdougall, P.P., Robinson, R.B. Jr., and DeNisi, A.S., (1992). "Modeling new venture performance: An analysis of new venture strategy, industry structure, and venture origin”. Journal of Business Venturing, 7(4), pp. 267-289.

Marsili, O., (2002). “Technological regimes and sources of entrepreneurship". Small Business Economics, 19(3), pp. 217-231.

Mata, J., (1994). "Firm growth during infancy”. Small Business Economics, 6 (1), pp. 27-39.

Mata, J., and Portugal, P. (1994). "Life duration of new firms". The Journal of Industrial Economics, 42(3), pp. 227-245.

Mata, J., and Portugal, P., (2004). "Patterns of entry, post-entry growth and survival: A comparison between domestic and foreign owned firms". Small Business Economics, 22 (3-4), pp. 283-298.

Modigliani, F., and Miller, M.H., (1958). "The cost of capital, corporate finance and the theory of investment”. The American Economic Review, 48(3), pp. 261-297.

Modigliani, F., and Miller, M.H., (1963). "Corporate income taxes and the cost of capital: A correction”. The American Economic Review, 53 (3), pp. 433-443.

Morris, M.H., Lewis, P.S. and Sexton, D.L., (1994). "Reconceptualizing entrepreneurship: An input-output perspective”. SAM Advanced Management Journal, 59(1), 21-31.

Muñoz-Bullon, F., Sanchez-Bueno, M.J., and Vos-Saz, A., (2015). "Startup team contributions and new firm creation: the role of founding team experience". Entrepreneurship \& Regional Development, 27 (1-2), pp. 80-105.

Murphy G.B., Trailer J.W. and Hill R.C., (1996). "Measuring performance in entrepreneurship research”. Journal of Business Research, 36 (1), pp. 15-23.

Musso, P., and Schiavo, S., (2008). "The impact of financial constraints on firm survival and growth". Journal of Evolutionary Economics, 18 (2), pp. 135-149.

Myers, S.C., (1984). "The capital structure puzzle". The Journal of Finance, 39 (3), pp. 575-592.

Myers, S.C., and Majluf, N.S., (1984). "Corporate financing and investment decisions when firms have information that investors do not have". Journal of Financial Economics, 13(2), 187-221.

Oprea, R., (2014). "Survival versus profit maximization in a dynamic stochastic experiment". Econometrica, 82(6), pp. 2225-2255.

Paul, S., Whittam, G., and Wyper, J., (2007). "The pecking order hypothesis: does it apply to startup firms?” Journal of Small Business and Enterprise Development, 14 (1), pp. 8-21.

Parker, S.C., and Van Praag, C.M., (2006). "Schooling, capital constraints, and entrepreneurial performance: The endogenous triangle”. Journal of Business \& Economic Statistics, 24 (4), pp. 416-431.

Persson, H. (2004). "The survival and growth of new establishments in Sweden, 1987-1995". Small Business Economics, 23(5), pp. 423-440.

Rauch, A., and Rijsdijk, S.A., (2013). "The effects of general and specific human capital on longterm growth and failure of newly founded businesses". Entrepreneurship Theory and Practice, 37 (4), pp. 923-941.

Reynolds, P.D., (2016). "Start-up actions and outcomes: What entrepreneurs do to reach profitability". Foundations and Trends in Entrepreneurship, 12(6), 443-559.

Santarelli, E., and Vivarelli, M., (2007). "Entrepreneurship and the process of firms' entry, survival and growth". Industrial and Corporate Change, 16 (3), pp. 455-488. 
Saridakis, G., Mole, K., and Storey, D.J., (2008). “New small firm survival in England”. Empirica, 35 (1), pp. 25-39.

Saridakis, G., Mole, K., and Hay, G., (2007). Do liquidity constraints in the first year of trading reduce the likelihood of firm growth and survival? Evidence from England. Institute for Small Business \& Entrepreneurship. 7-9 November 2007 - Glasgow, Scotland. http://www. researchgate.net/publication/237261185_Do_Liquidity_Constraints_in_the_First_year_of_ Trading_Reduce_the_Likelihood_of_Firm_Growth_and_Survival_Evidence_from_England.

Sharma, A., and Kesner, I.F., (1996). "Diversifying entry: Some ex ante explanations for postentry survival and growth”. Academy of Management Journal, 39 (3), pp. 635-677.

Stinchcombe, A.L., (1965). Social structure and organizations. In Handbook of Organizations, Edited by March, J.G., Rand McNally, Chicago, IL, pp. 142-193.

Strotmann, H., (2007). "Entrepreneurial survival”. Small Business Economics, 28(1), pp. 87-104.

Stucki, T., (2014). "Success of start-up firms: the role of financial constraints". Industrial and Corporate Change, 23(1), pp. 25-64.

Suárez, F.F., and Utterback, J.M., (1995). “Dominant designs and the survival of firms”. Strategic Management Journal, 16(6), pp. 415-430.

Tveterås, R., and Eide, G.E., (2000). "Survival of new plants in different industry environments in Norwegian manufacturing: A semi-proportional Cox model approach”. Small Business Economics, 14(1), pp. 65-82.

Van Auken, H., (2005). "Differences in the usage of bootstrap financing among technology-based versus nontechnology-based firms”. Journal of Small Business Management, 43(1), pp. 93-103.

Vázquez-Rozas, E., Gómes, S., and Vieira, E., (2010). "Entrepreneurship and economic growth in Spanish and Portuguese regions". Regional and Sectoral Economic Studies: RSES, 10(2), pp. 95-110. http://www.usc.es/economet/reviews/eers1028.pdf.

Winborg, J., (2009). "Use of financial bootstrapping in new businesses: a question of last resort?". Venture Capital, 11(1), pp. 71-83.

Winborg, J., and Landström, H., (2001). "Financial bootstrapping in small businesses: Examining small business managers' resource acquisition behaviors". Journal of Business Venturing, 16 (3), pp. 235-254. 